\title{
DOKTRIN ESKATOLOGI AL-GHAZALI DALAM MENANAMKAN KARAKTER DI PONDOK PESANTREN SURYABUANA MAGELANG
}

\author{
M. Mustholiq Alwi \\ Mahasiswa Pascasarjana Jurusan PAI IAIN Salatiga \\ allwebe9@gmail.com
}

\begin{abstract}
Islamic boarding school is a place in structuring characters and developing humans as a whole that can create advantages for surroundings. The purpose of this research is to reveals the materials and resources used in structuring characters in the Islamic boarding schools Suryabuana in forming virtuous ethical considerate Moslem generation. The methods of this study is field research. The results show that (1) the eschatological doctrine al-Ghazali is already internalized in the form of curriculum and teaching materials in the Islamic boarding school of Suryabuana. (2) the Islamic boarding schools of Suryabuana implies the doctrine of al-Ghazali eschatology through religious activities such as wirid, tahlil, mujahadah, and other forms of worships including spiritual science of mukasyafah and mu'amalah.
\end{abstract}

Keywords: Doctrine, eschatology, character building.

\begin{abstract}
Abstrak
Pondok pesantren sebagai tempat dalam penanaman karakter dan sarana membangun manusia yang sempurna, yang bisa menciptakan kebaikan dilingkungannya. Tujuan penelitian ini adalah pada materi-materi dan sumber-sumber penanaman karakter yang digunakan di pondok pesantren Suryabuana dalam membentuk generasi seorang muslim ahli ibadah, beretika, dan peduli sosial. Metode yang digunakan dalam penelitian ini adalah field research. Hasil penelitian ini menunjukkan bahwa (1) doktrin eskatologi al-Ghazali sudah termanifestasikan dalam bentuk kurikulum dan materi ajar di pondok pesantren Suryabuana. (2) Pondok pesantren Suryabuana mengimplikasikan doktrin eskatologi al-Ghazali lewat kegiatankegiatan keagamaan, seperi wirid, shalawat, tahlil, mujahadah, dan ibadah-ibadah lain, yang berkaitan dengan ilmu akhirat seperti ilmu mukasyafah dan ilmu mu'amalah.
\end{abstract}

Kata Kunci: doktrin, eskatologi al-Ghazali, dan karakter. 
INJECT: Interdisciplinary Journal of Communication, Vol.2, No.2, Des. 2017: h. 275-294

\section{Pendahuluan}

Islam di Indonesia merupakan manifestasi Suni yang dirumuskan dan dikukuhkan oleh Madrasah Nizhamiyyah pada abad 11 sampai $13 \mathrm{M}$. Susunan kurikulum yang ada diklsifikasikan dalam tiga fokus dasar-dasar pendidikan agama Islam oleh para guru dan pejabat pemerintah saat itu, seperti menentukan dalam aqidah, syari'ah, dan tasawuf. Menurut Fazlur Rahman (1958:92) mengatakan bahwa Madarsah Nizhamiyyah merupakan instansi pendidikan terdepan pada masanya, dan mempunyai banyak guru yang ahli dalam bidang keagamaan, salah satunya seorang sufi dan teolog yang sangat terkemuka yaitu Imam al-Ghazali. Al-Ghazali mempunyai pengaruh besar dalam perkembangan kurikulumnya.

Menurut Ira. M. Lapidus (2000:152) mengatakan bahwa al-Ghazali, sebagai guru besar umat muslim, ajarannya lebih menekankan terhadap dimensi eskatologi, karena visi keagamaan dan eskatologi menuntun manusia untuk memfokuskan terhadap kehidupan di akhirat. Al-Quran memerintah manusia untuk beriman kepada Allah SWT dan patuh terhadap kehendak-Nya. Menurut Fatiyah Hasan. S (1986:58) mengatakan bahwa kecenderungan sufistik dalam ajaran eskatologinya sering terealisir dalam menetapkan sesuatu berdasarkan kemanfaatannya, baik di dunia maupun di akhirat, sehingga ajaran-ajarannya kental dengan subtansi keagamaan. Menurut Abudin Nata (2001:41) mengatakan bahwa ilmu keyakinan terhadap akhirat, merupakan ilmu para shiddiqin dan muqarrabin, yang sangat penting bagi kehidupan manusia. Menurut Ibrahim Madkour (2004:74) dalam pandangan al-Ghazali akal merupakan penopang dalam berpikir segala ilmu, akan tetapi akal mempunyai batas-batas tertentu dan hanya naql lah yang bisa melewati batas ini. Naql yang bersifat transendental juga mengarahkan manusia menuju keselamatan dunia dan akhirat.

Menurut Djohan Efendi (2010:38) mengatakan bahwa muslim Indonesia mayoritas menganut ideologi Suni, melihat dari masuknya Islam ke Indonesia menurut sejarawan sekitar abad 13 masehi, yang 
mana masih dalam hegemoni Suni. Model penyebaran Islam pada saat itu sampai sekarang yaitu dengan mendirikan lembaga pendidikan Islam berupa pondok pesantren. Menurut Asrori S. Karni (2009:XXIV) mengatakan bahwa pondok pesantren merupakan wadah untuk mengembangkan pendidikan Islam yang paling strategis, menurut Nurcholis Madjid (2005:273) mengatakan bahwa orang tua mengupayaka anaknya agar berkode etik sesuai tuntunan al-Quran, mempercayakan pendidikan anaknya di pondok pesantren. Pondok pesantren yang mempunyai karakter pendidkan Islam Suni adalah pondok pesantren Suryabuana Pakis, kabupaten Magelang, Jawa Tengah. Pondok pesantren tersebut mempunyai geneologi keilmuan dengan para tokoh-tokoh Islam Suni seperti al-Ghazali. Materi pendidikannya berupa kitab-kitab yang bercorakkan keilmuan Suni, seperti ajaran aqidahnya yang menganut Abu Hasan alAsy'ari, fiqhnya menganut salah satu dari empat mazhab, dan mengikuti sufistik al-Ghazali. Perwujudan penanaman karakter santri sebagai manifestasi dokrin eskatologi merupakan sebuah keharusan, karena doktrin tersebut yang akan membangun karakter santri, sebagai muslim yang ahli ibadah dan ahli amaliyyah (kebaikan). Pesantren berupaya untuk mewujudkan hal tersebut dengan mengajarkan para santrinya untuk hidup sederhana, tidak hedon, dan lebih memikirkan kehidupan di akhirat, karena hidup di dunia hanya ibarat mampir ngombe.

\section{Permasalahan}

Penanaman karakter merupakan sebuah proyeksi bagi semuga lembaga pendidikan, dalam penanaman karakter sebuah instansi pendidikan mempunyai rujukan tersendiri dalam membangunnya, seperti halnya pondok pesantren Suryabuana yang mengacu penanaman karakternya dengan doktrin eskatologi al-Ghazali. Penelitian ini akan memfokuskan pembahasannya tentang bagaimana doktrin eskatologi alGhazali masuk dalam kurikulum dan amaliah santri pondok pesantren Suryabuana, Magelang. 
INJECT: Interdisciplinary Journal of Communication, Vol.2, No.2, Des. 2017: h. 275-294

\section{Doktrin Eskatologi}

Menurut Syaiful Rahman (2014:409) doktrin adalah konsep ajaran yang bersistem, sedangkan doktrin Islam sebuah ajaran yang bersumber dari Al-Quran dan Hadis, yang diajarkan Nabi Muhammad dan diinterpretasikan oleh para ulama. Menurut Peter Adam (1981:68) mengatakan bahwa eskatologi yaitu sebuah doktrin tentang keyakinan yang berhubungan dengan kejadian-kejadian akhir hidup manusia seperti kematian, hari kiamat, hari pembalasan dan sebagainya, intinya setelah nyawa manusia terlepas dari tubuhnya, maka akan ada kehidupan abadi, yaitu akhirat, al-Ghazali (1992:44). Menurut Sibawaihi (2004:72) doktrin eskatologi al-Ghazali merupakan pendidikan yang penting dalam dunia muslim, karena konsep-konsep eskatologi menjadi pilar bagi tegaknya aqidah seorang muslim. Menurut Margareth Smith (1994:55) bahwa Fazlur Rahman seorang pemikir muslim kontemporer, berpendapat yang sama dengan al-Ghazali, bahwa semua doktrin yang berasal dari ajaran al-Quran tidak bisa dilepaskan dengan doktrin eskatologi. Islam dan iman adalah tentang hukum akhirat dan dunia, manusia tidak akan mencapai kebahagiaan yang sempurna tanpa iman, dan wajib bagi orang beriman tidak hanya meyakinkan dalam hati dan pembenaran dalam lisan, akan tetapi juga harus dengan rentetan amal yang mengkarakter. Seperti itu juga al-Ghazali, menuntut orang beriman agar merealisasikan keimanannya melalui perilaku yang mengkarakter.

Menurut Thomas Licona (1991:51) bahwa karakter merupakan gabungan tiga komponen yang inheren, yaitu tentang pengetahuan moral, keinginan sebagai orang bermoral, dan melakukan kebiasaan perilaku orang yang bermoral. Menurut Lilik Sriyanti (20011: 159) dalam teori need milik Maslow, kebutuhan tertinggi manusia akan terpuaskan ketika dia bisa melakukannya. Menurut Belferik manulang (2013:2) bahwa karakter watak utama yang membentuk manusia berkualitas, yang mengutamakan budi pekerti. Menurut Syaifudin Zuhri (2011:292-293) 
pendidikan karakter adalah sebuah sistem yang menanamkan nilai-nilai karakter pada peserta didik, agar menjadi insan kamil. Berarti pendidikan karakter sesungguhnya tidak harus menggunakan kurikulum yang formal, seperti di pondok, cukup dengan hiden curriculum. Menurut Kamin Sukardi (2012: 280) pendidikan karakter tidak selalu diajarkan dalam kelas, namun dilakukan secara simultan dan berkelanjutan di dalam dan di luar kelas, yang terpenting dalam pendidikan karakter bukanlah transfer pengetahuannya, tapi transfer nilai kehidupan yang tercerminkan dalam perilaku kesehariannya.

Menurut Gamal Abdul Nasir Zakaria (2010:46), penggunaan istilah pondok pesantren sebagai lembaga Islam tradisional tidaklah hanya khusus di Jawa saja, tetapi di dunia dan di daerah rumpun Melayu juga menggunakan, hanya saja di lain tempat mempunyai nama berbeda, seperti di Aceh bernama Dayah, dan di Minangkabau bernama Surau. Pondok pesantren adalah salah satu dari sekian banyak institusi pendidikan Islam yang ada di dunia, dan diyakini sebagai pendidikan Islam di indonesia yang tertua, dilain itu pondok pesantren juga menjadi salah satu alternatif ekspansi Islam.

Doktrin eskatologi al-Ghazali merupakan seluruh ajaran yang ada dalam al-Qurantanpa membatasi tentang keimanan pada hari akhir. Cakupan dari gambaran eskatologi al-Ghazali diawali dengan konsep: Kematian (makna dan terjadinya kematian), Alam Barzakh, Hari Kiamat (peristiwa, kebangkitan dan pengadialan), Surga dan Neraka, akan tetapi juga diterangkan, bahwa paling utamanya sebuah amal adalah islam, dan paling utamanya islam adalah iman, sedangkan keimanan seorang muslim terhadap hari akhir dan al-Quran harus termanifestasikan dalam kehidupan sehari-hari sebagai manusia berilmu dan mempunyai karakter, dengan memahami kebaikan moral, menginginkan menjadi orang yang bermoral, dan menjadikan moral tersebut sebagai sebuah kebiasaan yang terbangun dalam kehidupan sehari-hari, sehingga dia merasakan 
kepuasan batin, dengan cara berkata santun dan berperilaku sesuai kode etik. Jadi doktrin eskatologi al-Ghazali adalah semua pendidikan yang ada dalam al-Quran dan Hadis, karena semua pendidikannya pasti berorentasi pada keselamatan dunia dan akhirat, sedangkan orang yang ingin selamat di dunia akhirat, maka dia harus menanamkan karakter kebaikan dalam hidupnya, dengan bertutur kata dan berperilaku yang baik pula. Pondok pesantren yang bercorakkan Sunni salafi (pesantren klasik di Indonesia) seperti pondok pesantren Suryabuana mengajarkan doktrin eskatol al-Ghazali sebagai misi membangun karakter santri agar kelak bisa mencerminkan perilaku insan kamil, seperti yang diajarkan dalam alQuran dan Hadis. Penanaman karakter tersebut dituangkan dalam visi dan misi yang dimiliki oleh pondok tesebut, dan materi-materi yang diajarkan dalam madrasah diniyyah sehari-hari dalam waktu dan tempat yang sudah ditentukan, selain materi ajar sebagai sarana penanman karakter sesuai doktrin eskatologi al-Ghazali, ada juga penanaman melalui amalanamalan ibadah dan yang lainnya.

\section{Doktrin Eskatologi al-Ghazali dalam Penanaman Karakter}

Karakter yang dibangun dalam pemikiran al-Ghazli dituangkan dalam beberapa kitabnya, salah satunya yang paling penting adalah pendidikan karakter yang didasari dengan doktrin eskatologi sesuai disiplin ilmu yang sudah beliau kodifikasi, berikut adalah konsep doktrin eskatologi dalam kitab-kitab al-Ghazali untuk membangun pendidikan karakter:

Al-Ghazali membuat konsep keilmuan tentang eskatologi dalam kitab (Ihya' Ulumuddin: 20-21) sebagai berikut:

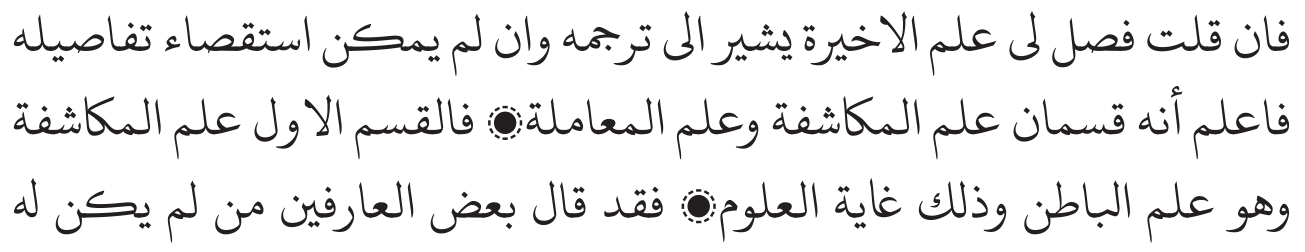




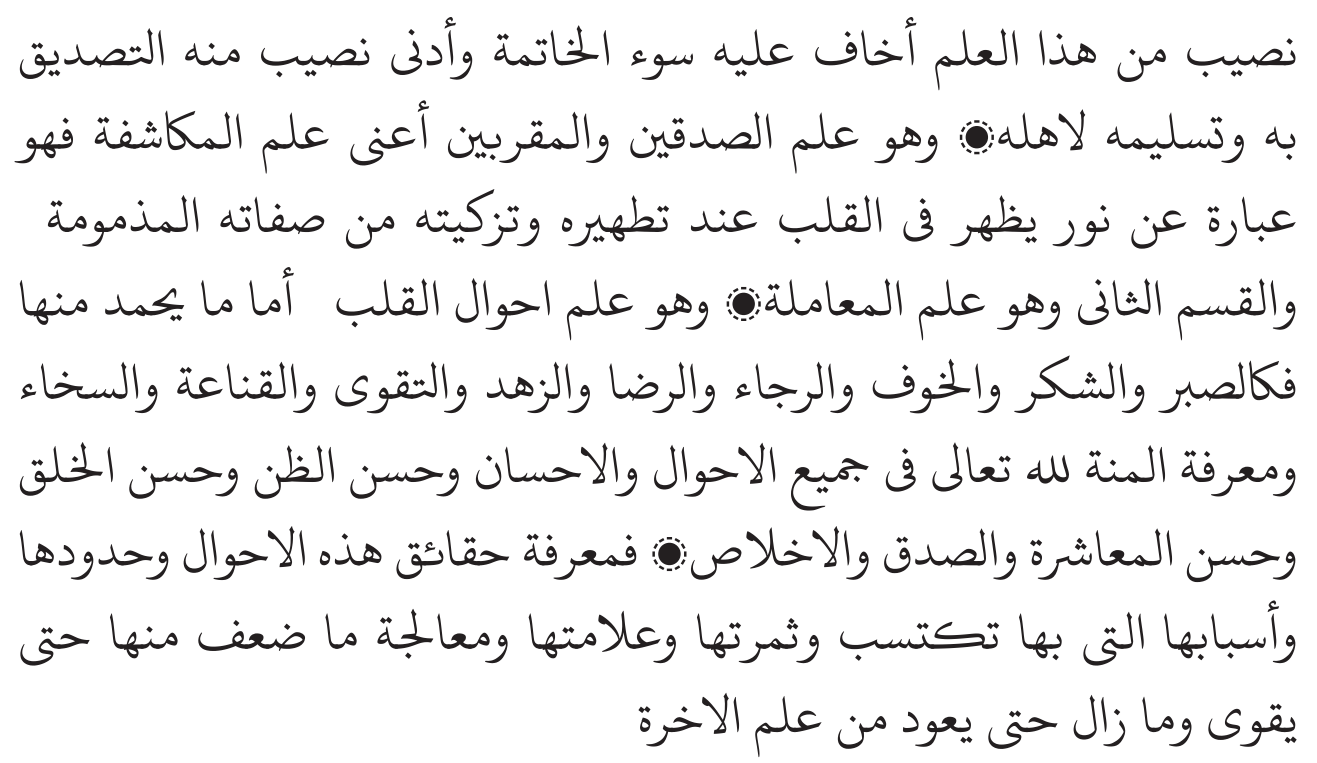

Artinya: "Imam Ghozali berpesan: Jika aku ditanya oleh seseorang, "buatkanlah aku perincian tentang sebuah ilmu jalan menuju akhirat yang mengisyaratkan penjelasan ilmu tersebut, walaupun tidak maksimal (penanya belum bisa melaksanakan) perincianya". ketahuilah kamu sekalian, bahwa sesungguhnya ilmu (akhirat) itu ada dua, yaitu: ilmu mukasyafah dan ilmu muamalah. Pembagian Ilmu jalan menuju akhirat yang pertama: Ilmu mukasyafah yaitu ilmu hati (untuk mengetahui kesaan Alloh dengan segala macam bentuknya, seperti Ilmu iman, yakin dan ilmu makrifat kepadaNya), hal itu menurut ImamGhozali merupakan puncaknya ilmu. Sebagian ulama ahli makrifat telah berkata bahwa "Barang siapa tidak bisa mengambil/ memiliki bagian dari ilmu itu, maka ditakutkan pada akhirnya su'ulkhatimah. Ilmu mukasyafah juga merupakan ilmunya orang-orang yang suka terhadap kebenaran dan yang suka mendekatkan diri kepada Allah, saya tegaskan lagi bahwa ilmu mukasyafah adalah sebuah pengibaratan cahaya hati yang murni dari sifat madzmumah. Adapun pembagian yang kedua: Ilmu muamalah yaitu sebuah ilmu yang membahas perbuatan hati dari perspektif (terpuji atau tercela), adapun yang termasuk perbuatan hati terpuji ialah sabar, syukur, takut akan murka Allah bersamaan dengan mengharap (ridha Allah), ridha, zuhud, taqwa, qona'ah, dermawan, meyakini akan anugerah Allah terhadap segala hal, ihsan, dan khusnudzon terhadap Alloh, berbudi pekerti, bergaul dengan baik, jujur, serta ikhlas, maka mengetahui beberapa hakikat seputar ilmu (akhirat), batasan-batasan, dan beberapa sebab-sebabnya sehingga menghantarkan ke sebuah hasil-hasil, dan tanda-tandanya, dan meningkatkan sifat mahmudah dari keterpurukan, tidak pernah melepaskan diri dari sifat-sifat mahmudah, itu 
INJECT: Interdisciplinary Journal of Communication, Vol.2, No.2, Des. 2017: h. 275-294

merupakan sebuah ilmu akhira".

Kitab al-Ghazali selain Ihya' Ulumuddin yang membahas tentang doktrin eskatologi yaitu Minhaj al-'Abidin, Ayyuha al-Walad, Bidayah alHidayah, Al-Munkid min al-Dholal dan yang lainnya, berikut adalah kutipan tentang doktrin eskatologi dalam kitab:

Minhaj al-'Abidin: 6-7

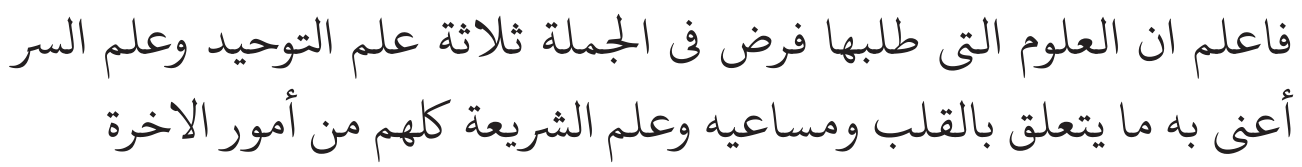

Artinya: "Ketahuilah sesungguhnya ilmu yang wajib dipelajari itu ada tiga jumlahnya: yaitu ilmu tauhid, ilmu sirr, maksudnya adalah yang berhubungan dengan hati dan apa yang diusahakannya, dan ilmu syari'at. Semua itu adalah perka akhirat."

Ayyuha al-Walad: 16

معنى التذكير أن يذكر العبد نار الاخرة وتقصير نفسه في خدمة الخالقية

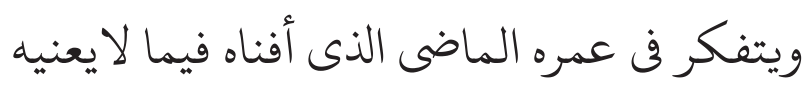

Artinya: "Makna dari kata التذكير (orang yang sering mengingat) yaitu ketika seorang hamba ingat akan api neraka pada hari akhir dan dia ingat bahwa jiwanya dalam beribadah kepada Penciptanya, dan dia ingat pula terhadap umurnya dimasa lalu yang telah dia rusak dan tidak digunakan sebagai mana mestinya."

Bidayah al-Hidayah: 47

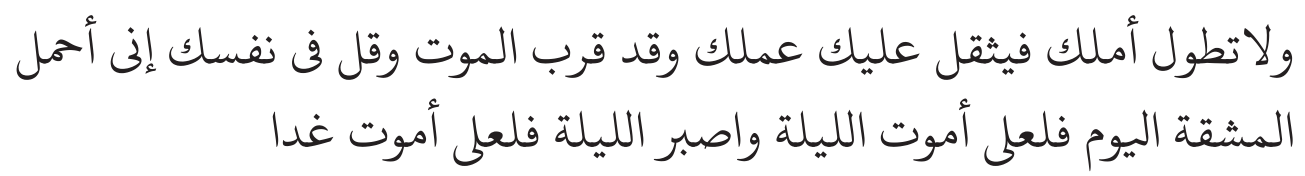

Artinya: "Janganlah kamu terlalu banyak angan-angan sehingga membebani kehidupanmu dan sungguh mendekatkan pada kematian, dan ucapkanlah pada dirimu sesungguhnya aku menanggung beban pada suatu hari, dan mungkin 
hingga mati pada malam hari, maka aku tetap sabar dan mungkin juga aku besok akan mati."

Al-Munkid min al-Dholal: 93

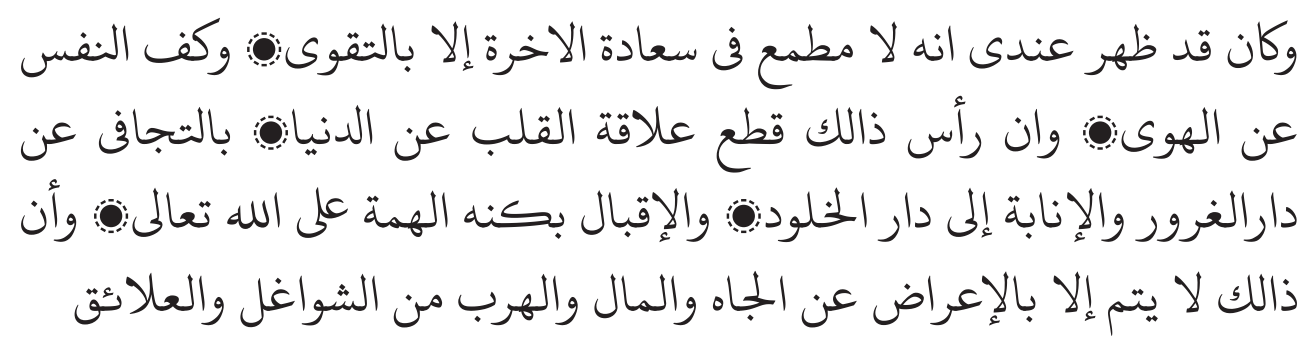

Artinya: "Dan menurutku telah jelas, bahwa tidak ada hal apapun yang dapat membawa menuju kebahagiaan ahirat, kecuali hanya dengan taqwa, dan menjaga jiwa dari hawa nafsu. Sedangkan inti dari keduanya adalah dengan memutuskan bergantungnya hati dari dunia, yaitu dengan cara bergeser dari dunia bujuk rayu menuju dunia pasti, dan menerima anugerah alloh dengan benar-benar melaksanakan, Semua itupun belumlah sempurna kecuali dengan berpaling dari harta dan tahta, serta meninggalkan beberapa hal yang membuat jiwa tersibukakan diri sehingga lupa, dan beberapa hal yang menyebabkan bergantung sehingga melupakan."

Pemikiran asketis al-Ghazali sangatlah nampak pada keterangan yang terkodifikasi dalam kitab-kitabnya. Pemahaman yang bisa diambil dari kutipan redaksi kitab al-Ghazali di atas adalah ajaran-ajarannya yang selalu menuntun manusia agar selalu mempelajarinya untuk mengedepankan ilmu akhirat, yang cakupannya tentang ilmu mukasyafah dan ilmu mu'amalah. Ilmu-ilmu tersebut yang akan menuntun manusia agar menjadi manusia yang berkarakter, karena kedua ilmu tersebut mengajarkan tentang pemikiran eskatologi al-Ghazali. Fokusnya adalah ilmu tentang pengetahuan hati kepada Allah dan sifat-sifatnya, dan ilmu tentang baik dan buruknya perilaku manusia sesuai tuntunan al-Quran dan Hadis.

Ajaran-ajaran al-Ghazali memang sudah mendarah daging di dunia pendidikan muslim Indonesia, khususnya pondok pesantren. 
Penerapan materi ajarnya yang dilakukan di pondok pesantren, tentunya mempunyai kemiripan antara yang satu dengan yang lainnya, hanya saja ketika melaksanakan pembelajaran, ada yang menekankan pendidikan dalam kelas dan ada juga pendidikan di luar kelas. Pendidikan di dalam kelas sudah menjadi ciri khas bagi pendidikan yang sudah biasa dilakukan, itu untuk memperkaya sisi kognitif tentang materi yang diajarkan, seperti juga eskatologi al-Ghazali, sedangkan pendidikan di luar kelas cara menanamkan doktrin eskatologi al-Ghazali dengan mengarahkan santri untuk melakukan ibadah sesuai ajaran al-Ghazali.

\section{Metode Penelitian}

Peneliti menggolongkan penelitian ini pada penelitian lapangan. Penelitian lapangan merupakan penelitian yang dilakukan secara intensif, terperinci dan mendalam terhadap suatu objek tertentu dengan mempelajarinya sebagai suatu kasus (Moleong, 2005:9). Dengan metode ini peneliti akan mengupas doktrin eskatologi al-Ghazali yang diajarkan dalam pesantren dan memahami secara perinci terhadap aplikasinya dalam kehidupan sehari-hari.

Penelitian ini menjadikan pengajar pondok pesantren Suryabuana sebagai subjek yang akan diteliti, selain pengajar, para santri juga terlibat sebagai subjek penelitian yang diharapkan bisa memberikan informasi terhadap doktrin eskatologi al-Ghazali yang diajarkan dan diimplementasikan dalam kehidupan sehari-hari. Literasi yang diajarkan di dalam pendidikan pondok pesantren tersebut merupakan objek penelitian yang akan dikaji keterkaitannya dengan geneologi keilmuan alGhazali sebagai salah satu panutan doktrin eskatologi umat Islam Suni.

Data yang akan diolah dalam penelitian ini bersumber dari literasi kitab-kitab kuning pendidikan yang ada dalam pondok pesantren Suryabuana, dan buku-buku hasil kodifikasi pondok tersebut untuk menyebarkan ajaran-ajaran dakwah keislaman yang digunakan semasa pengabdian di 
desa-desa yang membutuhkan penceramah atau guru agama.

Pengumpulan data untuk menyusun penelitian, peneliti menggunakan metode intervew sebagai bentuk komunikasi langsung (Gulo, 1991:86), sebagai alat penggali informasi dari pendidik ataupun peserta didik terhadap doktrin eskatologi al-Ghazali. Selain itu peneliti juga menggunakan metode library research sebagi pengumpulan data, agar bisa membandingkan antara berita yang disampaikan oleh informan dengan keilmuan yang ada dalam literasi pendidikan yang diajarkan, tentang doktrin eskatologi.

Analisis data yang digunakan dalam penelitian ini yaitu dengan menggunakan prisip-prinsip deskriptif (Sukardi, 2009:86). Dengan cara mengumpulkan data yang berkaitan dengan doktrin eskatologi alGhazali, setelah itu melakukan reduksi data untuk lebih memperjelas data yang valid dan yang tidak, dilanjutkan dalam langkah penyajian dengan menyusun antara data yang satu dengan yang lainnya, dan diakhiri dengan memberikan konklusi terhadap data-data yang ada.

\section{Pondok Pesantren Suryabuana}

Sebelum masukkedalam pendidikanyangbiasanya mengedepankan faktor kognitif, pondok pesantren Suryabuana mempunyai karakter khas dari pondok pesantren salaf pada umumnya. Walaupun dalam tujuannya sama yaitu membentuk karakter peserta didik yang mempunyai akhlakul karimah, peduli pada sesama, rajin beribadah, dan sifat-sifat yang lainnya.

Pendidikan pondok pesantren Suryabuana ditujukan dalam perubahan perilaku ubudiyyah khususnya. Pondok pesantren tersebut memanglah tidak muluk-muluk dalam berekspektasi dalam hasil pendidikannya, karena menurut mereka ketika seseorang bisa menata hatinya agar tetap bersih dan terjaga maka orang tersebut akan mempunyai emosi yang terkontrol, dan stimulus yang diberikan oleh hati bersih tersebut akan menimbulkan pemikiran yang positif, seketika itu hati sudah baik menjalar 
ke pemikiran yang positif, maka yang timbul dari ucapan pun kata-kata yang santun, sehingga semua hal tersebut akan termanifestasikan dalam perilaku kehidupan sehari-hari (Sirrullah, 20 Agustus 2017). Pengambilan materi pembelajaran untuk mengajarkan akhlak tersebut mengacu pada filosofi dari ayat berikut:

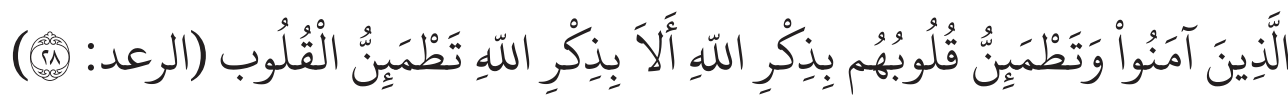

Artinya: "(yaitu) orang-orang yang beriman dan hati mereka menjadi tenteram dengan mengingat Allah. Ingatlah, hanya dengan mengingat Allah hati menjadi tenteram." (Q.S al-Ra'du: 28).

Pemfokusan dalam ibadah yang dilakukan pun dikembangkan dari ayat tersebut, mereka selalu membaca lafal tahlil setelah beribadah lima waktu secara berulang ulang, dengan menggerak-gerakkan anggota badan, yaitu kepala, sesuai arahan guru (Samsul Ma'arif, 08 Agustus 2017).

\section{Materi yang Diajarkan di Pondok Pesantren Suryabuana}

Dipandang dari sisi materi yang diajarkan. Pondok pesantren Suryabuana memang tidaklah memberikan materi yang banyak untuk memacu ranah kognitif bagi para santrinya, karena selain di situ memang secara fasilitas masih berkembang, di sisi lain selalu lebih mengedepankan ilmu khal, atau bisa dibilang fokus pendidikannya adalah tentang perilaku, seperti apa yang dibangun, bukan materi seperti apa dan sejauh mana penguasaannya. Karena dalam prinsip pendidikan karakter yang mereka bangun pada santrinya yaitu semua harus bermuara dari hati, bukanya kecanggihan pemikiran mereka dalam memahami ayat-ayat Allah atau pun Hadis Nabi, sesuai tuntunan Hadis yang mengatakan bahwa: "di dalam tubuh ada segumpal darah, apabila ia baik, maka baiklah seluruh jasad, dan apabila itu buruk, maka juga akan buruk semua seluruh jasad, dan ingatlah, itu adalah hati" (Bukhari:50). 
Materi pembelajaran yang digunakan sebagai sumbangsih ilmu pengetahuan tidak banyak. Kitab-kitab yang diajarkan di pondok pesantren Suryabuana tidak sekomplek pondok pesantren secara umumnya, karena di sana hanya mengajarkan beberapa kitab tentang bahasa, syari'ah Islam, dan kitab-kitab yang dianggap pokok, seperti: Uqudul Jumaan, Sirr al-Asrar wa Mazhar al-Anwar, dan Tajul Arus (Nida Utami, 21 Agustus 2017). Sesuai penuturan yang diberikan tersebut, ada ungkapan tidak langsung, bahwa pembelajaran yang mereka prioritaskan adalah tentang pembelajaran perilaku beribadah, dibuktikan dengan sedikitnya materi yang diberikan dalam kegiatan belajar mengajar.

Berlangsungnya pembelajaran sehari-hari dalam membentuk karakter santri pondok pesantren tersebut juga tidak sama dengan pondok pesantren pada umumnya, yang mana secara umum dalam pondok pesantren akan mempunyai jadwal yang pasti, untuk kegiatan belajar mengajar sehari-hari, berbeda dengan pondok pesantren Suryabuana yang cenderung mempunyai kajian kitab atau meteri lisan sangat sedikit, itu pun tidak diagendakan secara pasti, karena pengajaran yang dilaksanakan langsung berbentuk akhwal.

Pembelajaran langsung dilakukan oleh muballigh yang ada, mulamula dengan memberikan pemahaman tentang khakikat ketuhanan Allah Swt, setelah itu mereka diberikan amalan-amalan yang bisa menggiring diri mereka agar mempunyi kemauan, dan mampu untuk melaksakan amalan-amalan yang diajarkan, setelah mereka terbiasa dengan amalan-amalan tersebut mereka setiap minggu sekali diberikan reinsformen agar lebih memantapkan dalam hati mereka terhadap ajaran yang dilaksanakan, dan dalam acara bulanan pun mereka akan diberikan penguatan juga, agar karakter yang diinginkan segera terbangun sesuai dengan apa yang diinginkan. Jadi dalam pembelajarannya, bagaimana caranya agar para santri bisa terbiasa beribadah, setelah itu mereka bisa menjiwainya, mula-mula diajarkan ibadah setiap hari secara rutin, 
dengan wirid-wirid yang sesuai dengan anjuran di pondok pesantren, setelah itu setiap minggu diadakan penguatan pemahaman dengan cara musyawarah, yang dilakukan di masjid, dan setiap satu bulan sekali dilakukan mujahadah manaqib (Sirrulah, 08 Agustus 2017).

Pendidikan di pondok pesantren Suryabuana yang memang tidak memberikan penekanan materi secara kompleks pada santrinya, melakukan proses evaluasi pendidikannya dalam pondok pesantren tersebut pun mempunyai perbedaan dengan pondok pesantren yang lain. Pondok pesantren secara umumnya memberikan syahadah untuk mengetahui hasil belajar para santrinya, yang mungkin kalau dalam pendidikan modern, ini sering disebut dengan ijazah, sebagai bukti atas hasil pembelajarannya, apakah sudah sesui yang dituju ataukah belum sesuai dengan tujuan utama pembelajaran yang dilaksanakan dalam beberapa bulan atau tahun.

Pondok pesantren Suryabuana mengevaluasi para santri-santrinya dengan melihat perkembangan psikomotor mereka, apakah ada perbedaan atau tidak pada perilaku sehari-hari mereka. Semua perilaku para santri akan dievaluasi oleh para muballigh yang ada dalam kesehariannya, dan biasanya mereka yang sudah bisa mengamalkan ajaran-ajaran yang telah terkodifikasi dalam pendidikan di pondok pesantren tersebut, akan mengalami perubahan secara signifikan dalam perilaku atau pun yang lainnya (Samsul Ma'arif, 08 Agustus 2017).

\section{Penanaman Karakter di Pondok Pesantren Suryabuana.}

Penanaman karakter yang diinginkan dalam pembelajaran di pondok pesantren Suryabuana adalah karakter ahli ibadah, itu merupakan hal yang pokok dan diutamakan. Bermula dari itulah bisa dilihat pada kegiatan belajar mengajar yang tidak terlalu diberikan ruang banyak dalam kesehariannya, melainkan yang lebih diberi ruang kegiatan dalam kehidupan sehari-hari adalah pendidikan yang sifatnya pengembangan 
profesi dan amalan-amalan ubudiyah. Amalan ibadah yang dilakukan disana merupakan konversi dari kitab-kitab yang telah mereka pelajari (Ali Akib, 08 Agustus 2017), dengan mengambil filosofi sebagai berikut:

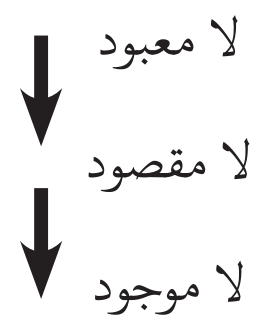

Gambar filosofi makna ibadah

Laa ma'buda yang berarti tidak ada yang wajib disembah (selain Allah). Menurut yang dituturkan oleh informan, perilaku yang pertama kali dilaksanakan oleh seorang hamba adalah menyembah, penyembahan seorang hamba terhadap Tuhannya merupakan tingkatan paling awal dari sebuah penghambaan, karena terkadang dalam beribadah masih banyak orang yang hanya menggugurkan kewajiban saja, selain itu, ada juga orang beribadah hanya karena menginginkan nikmat yang sementara dan bahkan hanya ingin mendapat reputasi lebih dari sesama, akan tetapi ketika orang tersebut bisa beribadah dengan bisa memadukan antara tubuh dan batinyyah, maka ibadahnya akan menjadi lengkap dan sempurna. Pelaksanaan pembangunan karakter di dalam pondok pesantren tersebut yaitu dengan memulai pembelajaran yang paling awal tersebut, dengan tujuan mempermudah pembelajaran bagi para santri baru. Ibadah sebagai kurikulum yang wajib dilaksanakan dalam menjalankan ajaran sesuai dengan doktrin eskatologi al-Ghazali adalah: Salat wajib lima waktu, zikir wajib setelah salat lima waktu (sesuai tuntunan mursyid), mujahadah mingguan, dan mujahadah bulanan.

Pembelajaran karakter ibadah dilaksanakan secara intens, sehingga para santri akan terbiasa untuk melaksanakannya, dan ketika para santri tidak melaksanakan, akan merasa ada yang hilang dalam diri mereka, 
bahkan mereka pun akan merasa malu secara sendirinya ketika tidak melaksanakan. Menurut penuturnan informan, bahwa ketika tingkatan ubudiyyah telah terlaksanakan maka santri secara otomatis pribadinya akan naik dalam tingkatan laa maqsuda.

Laa maqsuda yang berarti tidak ada tujuan atau maksud menyembah (selain Allah). Menurut penuturan informan, tingkatan ini merupakan kelanjutan dari tingkatan sebelumnya, akan tetapi belum tentu semua santri akan langsung memasuki tingkatan ini semua, setelah melaksanakn tingkatan yang pertama, ada yang dengan cepat naik ketingkatan ke dua, akan tetapi ada juga yang membutuhkan waktu yang lama, karena setiap manusia memiliki kecenderungan, keterbatasan dan kelebihan masingmasing (Baidhawy, 2011:144). yang sudah rutin dilaksanakan oleh santri dalam ibadah sesuai peraturan kurikulum yang sudah ditentukan. Ajaran ini bermaksud untuk membenahi niat yang dilakukan oleh santri ketika melaksanakan salat atau ibadah-ibadah lainnya, di sinilah salah satu metode tazkiyyah al-nafsi dilakukan, dengan memperbaiki niat yang dilakukan tatkala seseorang melaksanakan ibadah kepada Allah, mereka meniatkannya hanya kepada Allah semata, tidaklah dalam hati seseorang berniatkan selain Allah, seperti salat dengan berniatkan agar mendapat surganya Allah dan menjauhi nerakaNya, apalagi niat salat hanya sekedar menggugurkan kewajiban saja, yang secara langsung orang tersebut menjalankan ibadah kepada Allah hanya karena terpaksa.

Laa maujuda yang berarti tidak ada wujud di dunia ini (selain Allah). Ajaran ini merupakan tingkatan paling tinggi dalam sebuah peribadatan, menurut penuturan informan (Akib, 08 Agustus 2017). Dalam ibadah ketika seseorang sudah bisa melakukan secara kontinuitas, setelah itu dia akan merasakan nikmatnya ibadah setelah bisa menyatu dan melebur dalam kehidupan sehari-hari, sehingga ibadah tersebut menjadi kebutuhan dalam kehidupannya, dan orang tersebut beribadah dengan maksud mencari ridho Allah bukan karena takut ketika dicampakkan 
surgaNya dan takut akan siksa api nerakaNya.

Orang beribadah merupakan manifestasi rasa syukur akan segala nikmat Allah yang telah diberikan kepadanya, karena dia menyadari, bahwa semua yang ada di dalam dunia ini adalah ciptaanNya, dan dengan penuh kesadaran mengakui bahwa segala yang ada di dunia ini adalah bagian dari wujud transendentalNya. Pernyataan ini sesuai dengan filsafat Ibdu 'Arabi, bahwa manusia adalah emansi dari cahaya Uluhiyyah Allah, sehingga manusia bisa disimpulkan bahwa cahaya Uluhiyyah Allah merupakan wahdatul wujud (Syamsudin, 2014:190).

Tingkatan kepuasan tertinggi manusia dalam kehidupannya merupakan kepuasan batinnya, ketika dia bisa mengerti dan memaknai akan segala kehidupannya, masalah yang dia hadapi bisa diselesaikan, sehingga dia bisa menjadi sukses dan bisa mencerminkan perilaku sukses yang mengkarakter pada dirinya. Kebutuhan humanistik yang digambarkan oleh Maslow mengatakan manusia akan mencapai kepuasan tertinggi jika dia bisa melaksanakan keinginan batinnya, seperti mendekatkan diri kepada Allah, karena ketika manusia sudah bisa mencapai semua kesuksesan yang dia inginkan pelabuhan terahir dari tujuannya adalah kedekatannya pada Allah yang akan dia rasakan dari dia hidup sampai di akhirat kelak.

\section{Simpulan}

Dari uraian di atas dapat disimpulkan bahwa doktrin eskatologi al-Ghazali di pondok pesantren al-Ittihad Bringin dan Suryabuana Pakis, dengan rincian berikut: (1) Pondok pesantern al-Ittihad Bringin dalam menanamkan doktrin eskatologi al-Ghazali lewat kurikulum pendidikan sangat intens, melihat dari jadwal pembelajarannya setiap hari, dan materi-materi ajarnya yang mempunyai keterkaitan dengan ajaran-ajaran doktrin eskatologi al-Ghazali, dan dalam implementasi doktrin eskatologi pada pendidikan karakter juga sudah relevan dengan ajaran al-Ghazali. 
(2) Pondok pesantern Suryabuana Pakis dalam menanamkan doktrin eskatologi al-Ghazali lewat kurikulum pendidikan, belum bisa dikatakan maksimal, pasalnya dalam materi pendidikannya hanya diberikan ruang yang sedikit untuk waktu pembelajaran materi-materinya. Sedangkan dalam penerapannya, pondok pesantren Suryabuana sudah sangatlah intens, dilihat dari amalan-amalan yang berkaitan dengan doktrin eskatologi al-Ghazali yang dilakukan setiap hari oleh para santri, selain itu ada juga kegiatan ibadah yang dilakukan secara rutin satu minggu sekali, atau satu bulan sekali, sesuai dengan arahan dari para muballigh.

\section{DAFTAR PUSTAKA}

Adam, Peter. 1981. Dictionary of Philosophy. English: Joanna Cotler Book. Al-Daghomi, Ziad Khalil. Al-Ab'ad Al-Ma'rufiyyah Wa At-Tarbiyyah Lil-Iman bi Al-Akhirah Qiraatan fi Rasailil Al-Nur”, Studi Islam Yordania, Volume 04. Nomor 04. Juli 2007

Al-Ghazali. 1992. Ad-Durrah Al-Fakhirah fi Kasyf Ulum Al-Akhirah. Bairut: Mu'assasah Al-Kutub Al-Saqafiyyah. 2007. al-Munkid min al-Dholal. Jakarta: Haramain. 2005. Ayyuha al-Walad. Kediri: Petok. 2015. Bidayh al-Hidayah. Jakarta: Haramain. 2005. Ihya' 'Ulum al-Din Juz 1. Jakarta: Haramain. 2005. Ihya' 'Ulum al-Din Juz 4. Surabaya: Haramain. 2007. Mauidhotul Mu'minin. Surabaya: Imaratullah. 2007. Minhaj al-'Abidin. Semarang. Toha Putra.

Al-Zarmuzi, Syekh. 2004. Ta'limul Muta'alim. Khortoum: dar alsudaniyyah lil Kutub.

Ashari, Hasan dan Afandi. 1994. Pendidikan Tinggi Dalam Islam: Sejarah Dan Perannya Dalam Ilmu Pengetahuan. Jakarta: Logos Publishing Hous. Asri, Syamsul. "Jalan Lain Politik Profetik: Sejarah Sebagai Momen Eskatologis", Politik Profetik, Volume 02. Nomor 02. Juni 2013. Baidhawy, Zakiyuddin. 2011. Studi Islam. Yogyakarta: Insan Madani. 
Efendi, Djohan. 2010. Pembaruan Tanpa Membongkar Tradisi. Jakarta: Kompas.

Fikri, Ibnu. "Naskah Shahadat Sekarat: Konstruksi Nalar Sufístik Atas Kematian dan Eskatologi Islam di Jawa", Manassa, Volume 05. Nomor 02. Juli 2015

Gulo, W. 1991. Metode Penelitian dalam Teori dan Praktek. Jakarta: Rineka Cipta.

Imam Subqi, "Pola Komunikasi Keagamaan dalam Membentuk Kepribadian Anak", INJECT (Interdisciplinary Journal of Communication), Vol 1 No 2 Desember 2016.

Karni, Asrori S. 2009. Etos Studi Kaum Santri. Bandung: Mizan.

Kelompok Kreatif Baitul Kilmah. 2012. Rahasia Ilmu Para Wali Allah. Yogyakarta: Pustaka Marwa.

Lapidus, Ira. M. 2000. Sejarah Sosial Umat Islam. Terjemah Ghufron A. Mas'adi. Jakarta: Raja Grafindo Persada.

Licona, Thomas. 1991. Educating for Character. New York: Bantam Books. Madjid, Nurcholis. 2005. Islam Doktrin dan Peradaban. Jakarta: Paramadina. Madkour, Ibrahim. 2004. Aliran dan Teori Filsafat Islam. Jakarta: Bumi Aksara.

Manullang, Belferik. "Grand Desain Pendidikan Karakter Generasi Emas 2045", Pendidikan Karakter, Volume 03. Nomor 01. Februari 2013

Moleong, Lexy J. 2005. Metode Penelitian Kualitaif. Bandung: Remaja Rosdakarya.

Musadad, Asep Nasrul. "Eschatological Expression in The Holy Text", Internatonal Journal of Islamic Studies. Volume 02, Nomor 01. Juni 2014.

Nata, Abudin. 2001. Perspektif Islam Tentang Pola Hubungan Guru-Murid. Jakarta: Rajagrafindo.

Pulungan, Syahid Muammar. "Eskatologi dalam Al-Qur'an". Hikmah. Volume 08. Nomor 02. Juli, 2014.

Rahman, Fazlur. 1958. Propbecy in Islam: Philosophy and Ortodoxy. London: 
INJECT: Interdisciplinary Journal of Communication, Vol.2, No.2, Des. 2017: h. 275-294

George Alen \& Unwin Ltd,

Rahman, Syaiful. "Islam dan Pluralisme". Fikrah. Volume 02. Nomor 01. Juni 2014.

Sarjono, dkk. 2004. Panduan Penulisan Skripsi. Yogyakarta: Jurusan Pendidikan Agama Islam Fakultas Tarbiyah UIN Sunan Kalijaga Yogyakarta

Sibawaihi. 2004. Eskatologi Al-Ghazali dan Fazlur Rahman. Yogyakarta: Islamika.

Smith, Magareth. 1994. Al-Ghazali The Mytic. London. Luzac \& Co.

Sriyanti, Lilik. 2009. Teori-teori Pembelajaran. Salatiga: STAIN Salatiga Press.

Subagyo, Joko. 1991. Metode Penelitian dalam Teori dan Praktek. Jakarta: Rineka Cipta.

Sukardi, Kamin. "Potret Pendidikan Karakter di Pondok Pesantren Salafiah", Pendidikan Karakter, Volume 02, Nomor 03. Oktober 2012

Sukardi. 2009. Metodologi Penelitian Pendidikan Kpmpetensi dan Praktiknya. Jakarta: Bumi Aksara.

Sukmadinata, Nana Syaodih. 2012. Metode Penelitian. Yogyakarta.

Depublisher.

Sulaiman, Fatiyah Hasan. 1986. Sisitem Pendidikan Versi Al-Ghazaly. Bandung: Al-Ma'arif.

Syamsudin, Achmad Maimun. 2014. Tiga Mazhab Utama Filsafat Islam. Terj: Three Muslim Sages: Avicenna-Suhrawardi-Ibn 'Arabi. Jogjakarta: Irchisod.

Zakaria, Gamal Abdul Nasir. "Pondok pesantren: changes and its future", Islamic and Arabic Education, Volume 02. No 02. 2010

Zuhriy, M. Syaifuddien. "Budaya Pesantren dan Pendidikan Karakter Pada Pondok Pesantren Salaf". Pendidikan Karakter. Volume 19. Nomor 02. November. 2011. 